\title{
Coping Stress Pascacerai: Kajian Kualitatif Pada Ibu Tunggal
}

\author{
ARIO CHANDRA JONATHAN \& IKE HERDIANA*
}

Departemen Psikologi Kepribadian dan Sosial, Fakultas Psikologi Universitas Airlangga

\begin{abstract}
ABSTRAK
Penelitian ini bertujuan untuk mengetahui gambaran stres pascacerai dan strategi coping yang digunakan ibu tunggal yang bekerja. Pendekatan penelitian menggunakan deskriptif kualitatif dengan desain studi kasus. Karakteristik partisipan ibu tunggal, bekerja dan memiliki anak. Data diperoleh melalui wawancara terhadap partisipan yang bersangkutan disertai wawancara significant other. Analisis data yang digunakan dalam penelitian ini adalah teknik analisis data tematik. Hasil penelitian menunjukan gejala stres yang dialami partisipan berupa tekanan darah meningkat, sering menunda pekerjaan, mudah marah, perubahan pola makan, peningkatan konsumsi rokok, dan mengalami gangguan tidur. Sumber stres setiap partisipan merupakan orang ketiga dalam hubungan rumah tangga, serta penyusutan sumber daya ekonomi, sosial, dan psikologis. Strategi coping stress yang digunakan partisipan antara lain; planful problem solving, confrontative, seeking for social support, distance, escape/avoidance, positive reappraisal, self-control, dan acceptance responsibility.
\end{abstract}

Kata kunci: coping stress, ibu tunggal yang bekerja, stres pascacerai

\section{ABSTRACT}

This study aimed to discover the picture of post-divorce stress and the coping stress strategy of working single mother. This study used a qualitative descriptive approach with case study design. The characteristics of single mother participants are working and having child. The data obtained through interviews with the concerned participants accompanied by significant other interviews. Analysis of the data used in this study is thematic analysis data. The result showed that stress symptoms experienced by participants were in the form of increased blood pressure, often delay work, easy to get angry, diet changes, increased cigarette consumption, and sleep disorder. The sources of stress of all participants were third parties in their household, also the depreciation of economic, social and psychological resources. Coping stress strategy used by participants were planful problem solving, confrontative, seeking for social support, distance, escape/avoidance, positive reappraisal, self-control, dan acceptance responsibility.

Key words: coping stress, post-divorce stress, working single mother 
INSAN Jurnal Psikologi dan Kesehatan Mental, 2020, Vol. 5(1), 71-87, doi: 10.20473/jpkm.v5i12020.71-87

Dikirimkan: 15 Februari Diterima: 13 Mei 2020 Diterbitkan: 26 Juni 2020

Editor: Atika Dian Ariana

*Alamat korespondensi: Fakultas Psikologi Universitas Airlangga, Jl. Airlangga 4 -6 Surabaya. Pos-el: ike.herdiana@psikologi.unair.ac.id

Naskah ini merupakan naskah dengan akses terbuka dibawah ketentuan the Creative Common Attribution License (http://creativecommons.org/licenses/by/4.0), sehingga penggunaan, distribusi, reproduksi dalam media apapun atas artikel ini tidak dibatasi, selama sumber aslinya disitir dengan baik.

\section{P E N D A H U L U A N}

Berbagai macam persoalan dan musibah yang tidak terprediksi datang dalam keluarga dapat menimbulkan perpecahan dalam keluarga tersebut. Perpisahan yang paling banyak terjadi dalam rumah tangga adalah kematian dan perceraian. Kematian pada pasangan hidup dalam suatu keluarga merupakan peristiwa yang dapat mengganggu kehidupan emosional, mengubah hubungan individu dengan lingkungan sosialnya dan dapat menimbulkan permasalahan-permasalahan dalam kehidupan setelah ditinggalkan pasangan (Belsky, 1997). Glazer, dkk. (2010) berpendapat bahwa kematian berdampak pada berubahnya pola pengasuhan anak dan hubungan yang dihadapi pasangan yang masih hidup dengan orang lain dan diri sendiri (Pitasari \& Cahyono, 2014). Seseorang yang dalam keadaan kehilangan pasangan tersebut biasanya disebut dengan orang tua tunggal atau single parent.

Orang tua tunggal (single parent) menurut Hurlock (1999), adalah orang tua yang telah menduda atau menjanda entah bapak atau ibu, mengasumsikan tanggung jawab untuk memelihara anak-anak setelah kematian pasangannya, perceraian atau kelahiran anak diluar nikah (Fatimah \& Nurdin, 2015). Orang tua tunggal disini yang lebih sering ditemui adalah seorang ibu yang tanpa suami dan memiliki tanggungan sejumlah anak. Keluarga dengan ibu sebagai orang tua tunggal seringkali disebabkan oleh meninggalnya suami, perceraian, ibu yang tidak menikah dan remaja yang hamil di luar nikah (Aprilia, 2013).

Bagi seorang ibu, kehilangan suaminya merupakan tantangan yang amat berat. Hal tersebut dapat memberikan berbagai macam dampak entah itu fisik maupun psikologis bagi seorang ibu. Seorang single parent cenderung sibuk dengan pekerjaan kantor, sibuk mengurus anak, kurangnya waktu istirahat, sampai makanpun tidak teratur, dan hal tersebut sering kali terjadi pada single parent yang suaminya meninggal (Negeri, 2013). Selain dampak dari suami yang meninggal, penulis juga menemukan dampak yang lebih banyak dari sebuah perceraian. Hasil penelitian Nair dan Murray (2005) menyebutkan bahwa ibu dari keluarga bercerai memiliki stress yang lebih tinggi dibandingkan dengan ibu yang tidak bercerai.

Setelah perceraian, ibu mengalami penyusutan sumber daya penting dalam melakukan fungsi pengasuhan, yaitu hilangnya dukungan psikologis dan ekonomi dari pasangan, perubahan status, peran, dan krisis identitas, dan gangguan emosi, kesepian, merasa tak berdaya, tak memiliki harapan, dan kehilangan rasa percaya diri (Kotwal \& Prabhakar, 2009). Penyebab utamanya dari perceraian adalah perselingkuhan yang sebagiannya kerena dampak hubungan via sosial media, dan juga KDRT. Hubungan seksual pada remaja dan anak-anak semakin merebak yang juga berakibat pada peningkatan kasus kehamilan tidak dikehendaki (KTD), pernikahan usia dini, dan prostitusi anak dan remaja (Sasongko, 2014). 
Apabila individu dapat bertahan dengan situasi buruk tersebut sehingga lebih memilih untuk mengatasi atau meminimalisasi permasalahan, berarti individu berusaha melakukan mekanisme pertahanan diri atau bisa juga disebut dengan strategi coping (Papalia, dkk., 2009). Coping merupakan proses dimana seseorang mencoba untuk mengelola perbedaan yang dirasakan antara tuntutan dan sumber daya yang mereka nilai dalam situasi stres (Pitasari \& Cahyono, 2014). Usaha coping sangat penting untuk mengoreksi atau menguasai suatu masalah, serta membantu seseorang mengubah persepsinya mengenai ketidaksesuaian, toleransi atau penerimaan ancaman atau hal yang membahayakan, atau melarikan diri atau menghindari situasi (Lazarus \& Folkman, 1984). Dari beberapa penelitian terdahulu ditemukan bahwa ibu tunggal sebagai subjek penelitian yang mengalami stres adalah ibu tunggal yang sedang bekerja (Kusumastuti, 2014; Pitasari \& Cahyono, 2014; Asilah \& Hastuti, 2014; Nisa \& Lestari, 2016).

Berdasarkan pemaparan diatas, penelitian ini dilakukan dengan tujuan untuk mengetahui gambaran stres pascacerai dan strategi coping yang digunakan ibu tunggal yang bekerja.

\section{Ibu Tunggal Akibat Perceraian}

Menurut Qaimi (2003) seorang wanita sebagai orang tua tunggal adalah suatu keadaan dimana seorang wanita akan menduduki dua jabatan sekaligus, yakni sebagai ibu yang merupakan jabatan alamiah dan sebagai ayah. Ia akan memiliki dua bentuk sikap, sebagai wanita dan ibu harus bersikap lembut terhadap anaknya, dan sebagai ayah yang bersikap jantan dan bertugas memegang kendali aturan dan tata tertib, serta berperan sebagai penegak keadilan dalam kehidupan rumah tangga.

Seorang ibu memiliki peran ganda, yaitu sebagai ayah sekaligus ibu bagi anak-anaknya setelah terjadi perceraian (Asilah \& Hastuti, 2014). Perceraian yang disebabkan oleh perselingkuhan, menyebabkan adanya perasaan sakit hati pada ibu tunggal paska perceraian (Sari, 2013). Perilaku stres yang dimunculkan ibu tunggal adalah menangis, depresi, dan minder dengan statusnya (Naufaliasari \& Andriani, 2013).

\section{Stres}

Stres pada ibu tunggal adalah tekanan yang dialami ibu sebagai akibat dari sumber stres yang terjadi pada keluarga yang telah bercerai. Strss merupakan suatu kondisi yang disebabkan adanya ketidaksesuaian antara situasi yang diinginkan dengan keadaan biologis, psikologis atau sistem sosial individu tersebut (Sarafino, 1990). Perubahan pada individu akibat stres dapat dikelompokan dalam tiga kategori umum yaitu gejala fisik, gejala psikologis, dan gejala perilaku (Robbins \& Judge, 2007).

Pengaruh awal stres biasanya berupa gejala fisik. Stres dapat menyebabkan perubahan dalam metabolisme, meningkatkan detak jantung, menaikan tekanan darah, menimbulkan sakit kepala, dan memicu serangan jantung. Gejala psikologis stres dapat menyebabkan ketidakpuasan diri dengan pekerjaan, ketegangan, kecemasan, mudah marah, kejenuhan, dan sikap yang suka menunda pekerjaan. Gejala selanjutnya yang disebabkan oleh stres berkaitan dengan perilaku meliputi perubahan dalam hal produktivitas, kemangkiran, dan perputaran karyawan, perubahan dalam kebiasaan makan, pola merokok, konsumsi alkohol, bicara cepat, gelisah, dan gangguan tidur (Robbins \& Coulter, 2007).

Sumber stres yang berpotensi menyebabkan stres yakni konflik, perubahan kehidupan, dan pertengkaran sehari-hari. Penelitian ini berfokus pada indikator perubahan kehidupan menggunakan teori sumber stres yang dikemukakan oleh Atkinson (1987) dalam melihat faktor apa saja yang dapat menimbulkan stres pada ibu tunggal setelah bercerai dengan suaminya.

INSAN Jurnal Psikologi dan Kesehatan Mental

Tahun 2020, Vol. 5(1), 71-87

doi: 10.20473/jpkm.v5i12020.71-87 
Stressor yang menyebabkan stres pada individu akan menghasilkan respon dari individu tersebut. Respon tersebut dapat berupa respon yang positif maupun negatif. Namun di dalam penerapannya, cenderung pada respon negatif yang lebih dominan. Respon terhadap strss (Sarafino, 1990) diantaranya adalah; anxiety; anger dan aggression; apathy dan depression; dan cognitive impairment.

\section{Strategi Coping}

Coping adalah proses di mana individu mengelola tuntutan hubungan orang-lingkungan yang dinilai sebagai stres dan emosi yang mereka hasilkan. Coping sebagai usaha mengubah pemikiran atau tindakan untuk mengelola tuntutan internal dan eksternal yang dinilai berat dan melebihi sumber daya yang dimiliki individu. Menurut Lazarus dan Folkman (1984), coping adalah suatu proses di mana individu mencoba untuk mengelola jarak yang ada antara tuntutan-tuntutan (baik itu tuntutan yang berasal dari individu maupun tuntutan yang berasal dari lingkungan) dengan sumber-sumber daya yang mereka gunakan dalam menghadapi situasi stres.

Menurut Lazarus dan Folkman (1984), coping memiliki dua fungsi utama, yaitu problem-focused coping dan emotional-focused coping. Problem-focused coping merupakan pendekatan yang bertujuan untuk menurunkan tuntutan dari situasi stres atau memperluas sumber daya untuk menghadapinya. Pendekatan problem-focused digunakan ketika mereka percaya bahwa sumber daya atau tuntutan mereka dalam suatu situasi yang dapat berubah (Lazarus \& Folkman, 1984). Emotional-focused coping bertujuan untuk mengontrol respon emosional dalam situasi yang menyebabkan stres. Pendekatan emotional-focused digunakan ketika mereka percaya dapat melakukan hal kecil untuk merubah kondisi stress (Lazarus \& Folkman, 1984).

Folkman, dkk. (1986) mendeskripsikan beberapa macam strategi coping dalam problem-focused coping dan emotional-focused coping, yaitu antara lain planful problem solving (problem-focused), confrontative (problem-focused), seeking social support (problem/emotion-focused), distance (emotion-focused), escape/avoidance (emotion-focused), positive reappraisal (emotion-focused), self-control (emotionfocused), dan acceptance responsibility (emotion-focused).

\section{E T O D E}

\section{Desain Penelitian}

Penelitian ini menggunakan pendekatan kualitatif dengan tipe studi kasus intrinsik. Pendekatan kualitatif adalah metode penelitian yang ditempuh dengan menggunakan prosedur penelitian yang menghasilkan data yang bersifat deskriptif berupa kata-kata tertulis atau lisan dari narasumber yang ditemui dan diamati latar belakangnya secara menyeluruh (Moleong, 1998). Alasan menggunakan pendekatan kualitatif karena didasarkan pada fokus penelitian untuk mendapatkan hasil yang sesuai (Poerwandari, 2007), yakni mengetahui bagaimana gambaran stres dan strategi coping yang digunakan ibu tunggal pasca bercerai dengan suaminya dan bertanggungjawab mengasuh anak-anaknya.

Tipe penelitian yang digunakan pada penelitian ini adalah pendekatan studi kasus intrinsik karena bertujuan untuk mempelajari tentang fenomena unik yang difokuskan oleh penelitian. Teknik penggalian data yang digunakan dalam penelitian ini adalah pengisian lembar kuisioner dan wawancara yang dilakukan terhadap subjek dan significant other. 


\section{Partisipan}

Partisipan dalam penelitian ini diperoleh melalui informan yang mengetahui tentang keadaan partisipan sebagai seorang ibu tunggal akibat perceraian. Karakteristik partisipan dalam penelitian ini antara lain: wanita yang telah resmi bercerai dengan suaminya dan belum menikah lagi; memiliki anak kandung (satu atau lebih) dari mantan suaminya dan memiliki hak asuh penuh atas anaknya tersebut; menanggung beban hidup dan pendidikan anaknya yang sedang bersekolah atau kuliah; dan memiliki usaha pribadi atau pekerjaan tetap maupun sementara yang menjadi sumber pendapatan utama.

Tabel 1. Profil Partisipan Penelitian

\begin{tabular}{lccc}
\hline \multicolumn{1}{c}{ Aspek } & Partisipan 1 & Partisipan 2 & Partisipan 3 \\
\hline Usia & 56 tahun & 48 tahun & 47 tahun \\
Agama & Katolik & Islam & Kristen \\
Status saat ini & Bercerai & Bercerai & Bercerai \\
Pekerjaan & Dosen & PNS & Wiraswata \\
Pendidikan Terakhir & S1 & S1 & SMA \\
Penyebab & Suami berselingkuh, & Suami & Suami jarang memberi nafkah, \\
Perceraian & LDR, kurang & berselingkuh dan & pertengkaran rumah tangga, \\
& komunikasi & LDR & suami berselingkuh \\
Usia saat bercerai & 48 tahun & 40 tahun & 45 tahun \\
Status perceraian & Sah bercerai & Sah bercerai & Sah bercerai \\
$\begin{array}{l}\text { Dampak yang } \\
\text { dialami }\end{array}$ & Stres, finansial & Stres dan stigma & Stres, finansial melemah \\
\hline
\end{tabular}

\section{Analisis Data}

Penelitian ini, menggunakan teknik analisis tematik. Analisis tematik merupakan proses pengkodean informasi kualitatif melalui sebuah kode eksplisit berupa daftar tema-tema; sebuah model kompleks yang berisi tema, indikator, dan kualifikasi yang terhubung dalam kausalitas; atau sesuatu diantara kedua hal tersebut (Boyatzis, 1998). Analisis tematik berfungsi untuk menemukan pola dari bermacammacam informasi yang telah terkumpul (Poerwandari, 2007). Pendekatan yang digunakan dalam penelitian ini adalah pendekatan berdasarkan teori (theory driven).

\section{H A S I L P E NELIT I AN}

Penelitian ini menghasilkan data informasi mengenai gambaran stres pascacerai dan berbagai macam bentuk strategi coping yang digunakan ibu tunggal yang bekerja. Secara umum, dalam penelitian ini ditemukan perbedaan gambaran stres serta strategi coping-nya pada ketiga partisipan. 


\section{Gambaran Stres}

Gambaran stres yang ditunjukan ketiga partisipan dalam penelitian ini meliputi gejala stres, sumber stres, dan respon terhadap stres.

a. Gejala stres

Untuk mengetahui gejala-gejala stres yang dialami setiap partisipan pasca bercerai dengan suami, peneliti mengunakan kuesioner yang diadaptasi dari diagram gejala stres dari Robbins dan Coulter (2007).

Tabel 2. Hasil Kuesioner Gejala Stres

\begin{tabular}{llll}
\hline \multicolumn{1}{c}{ Indikator } & \multicolumn{1}{c}{ Partisipan 1 } & Partisipan 2 & \multicolumn{1}{c}{ Partisipan 3 } \\
\hline Gejala Fisik & $\begin{array}{l}\text { Tekanan darah } \\
\text { meningkat }\end{array}$ & - & Tekanan darah meningkat \\
Gejala Psikologis & $\begin{array}{l}\text { Sering menunda } \\
\text { pekerjaan }\end{array}$ & $\begin{array}{l}\text { Sering menunda } \\
\text { pekerjaan }\end{array}$ & $\begin{array}{l}\text { Mudah marah; Sering } \\
\text { menunda pekerjaan }\end{array}$ \\
& $\begin{array}{l}\text { Perubahan pola makan; } \\
\text { Gejala Perilaku }\end{array}$ & $\begin{array}{l}\text { Peningkatan } \\
\text { konsumsi rokok }\end{array}$ & $\begin{array}{l}\text { Perubahan pola makan; } \\
\text { Gangguan tidur }\end{array}$ \\
\hline
\end{tabular}

Dari hasil tersebut diketahui bahwa ketiga partisipan memiliki kesamaan gejala psikologis, yakni sering menunda pekerjaan. Partisipan kedua paling sedikit menunjukan gejala stres, sedangkan partisipan ketiga paling banyak menunjukan gejala stres.

\section{b. Sumber stres}

Sumber stres secara umum dapat dibagi menjadi tiga bagian yakni konflik, perubahan kehidupan, dan pertengkaran sehari-hari (Atkinson, 1987). Berdasarkan ketiga indikator tersebut peniliti berfokus pada bagian perubahan kehidupan, karena fokus penelitian ini adalah strategi coping stress pascacerai, maka perubahan kehidupan adalah indikator yang paling berkaitan. Perubahan kehidupan yang dimaksud dalam penelitian ini yakni menjanda, setelah sebelumnya memiliki pasangan lalu berpisah karena perceraian. Perceraian yang dibahas dalam penelitian ini terdapat dua indikator yakni faktor penyebab perceraian dan dampak perceraian.

Sumber stres yang membuat ketiga partisipan memutuskan untuk bercerai ialah adanya orang ketiga dalam hubungan rumah tangga mereka.

"Jadi gini ya Yok ya... Yang paling jelas, yang paling aku ndak bisa terima adalah karena adanya pihak ketiga ya..." (HC121018:50)

"Iya, karena ada perempuan lain..." (HC121018:52)

“...Sebenarnya faktor yang paling utama sih...karena orang ketiga..." (IF060119:16)

"Iya... Jadi, ya gimana mas ya ehahahaha... Ya kalaupun mau diuraikan kesimpulannya kan juga seperti itu gitu..." (IF060119:18)

"Ehm... yo iku, si Om nduwe wedok'an liyo Yo..." (AH090919:30)

Selain faktor penyebab perceraian, dampak dari perceraian juga dapat menjadi sumber dari stress yang dialami ketiga partisipan. Perceraian yang dialami partisipan berdampak pada faktor ekonomi,

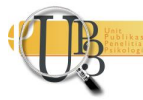


sosial dan psikologis. Hal serupa dikemukakan dalam penelitian terdahulu oleh Amato (2000) serta Kotwal dan Prabhakar (2009), dimana setelah perceraian ibu mengalami penyusutan sumber daya penting dalam melakukan fungsi pengasuhan, yaitu hilangnya dukungan psikologis dan ekonomi dari pasangan, perubahan status, peran, dan krisis identitas, dan gangguan emosi, kesepian, merasa tak berdaya, tak memiliki harapan, dan kehilangan rasa percaya diri.

Demi mencukupi kebutuhan hidupnya dan anak-anaknya pada masa awal pasca bercerai, partisipan 1 bekerja di dua tempat yang berbeda di hari yang sama. Sedangkan partisipan 2 tidak merasakan tekanan yang serius dalam finansial karena beliau memiliki pendapatan yang cukup serta mendapatkan tunjangan untuk sekolah putrinya dari mantan suaminya. Pasca bercerai dengan suami, partisipan 3 harus bekerja sebagai pedagang tahu guna mencukupi kebutuhan hidup keluarganya, dimana sebelumnya aktivitas beliau sehari-hari hanya sebagai ibu rumah tangga.

“...Ya, dari segi finansial ya cukup berat sih Yok. Makanya waktu itu sempat aku kerja double." (HC121018:78)

"Jadi aku kerja...ya dosen kalau sore, nah kalau pagi aku di kontraktor..." (HC121018:80)

"Ada, ya jelas ada ya. Kalau biasanya, ya meskipun tidak seratus persen, karena kan, dari keputusan pengadilan sendiri kan tunjangan yang diminta cuma untuk anak, istri kan endak..." (IF060119:30)

"Jadi anak itu kan, cuma kebutuhan sekolah aja, kalau kebutuhan makan kan masih tanggung jawab saya." (IF060119:32)

"He'em, finansial. Ya kamu ya tau dewe Ai pas masih sama papae Sinyo kan cuma ibu rumah tangga toh..." (AH090919:54)

"Nah lek sekarang ini ya paling mek ini, jual tahu pong punya'e cece'ne Ai yang produksi di Madiun..."

(AH090919:14)

Dari segi sosial, partisipan 1 merasakan tekanan sosial pascacerai berupa bullying dari saudarisaudari beliau pada dirinya dan kedua anaknya. Sedangkan partisipan 2 tidak merasa tertekan dalam pergaulan lingkungan sosial dan keluarga beliau pasca bercerai dengan suami. Pada partisipan 3, beliau mengaku tidak merasakan dampak perceraian dari segi sosial yang signifikan, melainkan hanya teguran dari pemimpin Gerejanya.

"Ehh...kadang-kadang itu Yok ya, mbakyu-mbakyuku dewe itu ya sempet mbully gitu..." (HC121018:108)

“...Jadi kadang aku di-bully di opo ae yo tak jarno ae... Bahkan kadang-kadang anak-anakku juga dijauhin sama misan-misanannya..." (HC121018:112)

"He'eh, tidak menge-judge seperti itu... Ternyata, saya punya pemikiran-pemikiran bahwa, orang diluaran pun menerima saya..." (IF060119:144)

“...kalau dari segi sosial, di lingkungan sosial gitu, Ai ngerasakan dampaknya nggak pasca cerai?" (A090919:83)

“Ehm... Gak ada e rasane Yo..." (AH090919:84)

“Paling ya dari ibu Gembala..." (AH090919:86)

Partisipan 1 menyatakan bahwa beliau justru merasakan stress pada saat sebelum bercerai yang didukung oleh hubungan jarak jauh. Sedangkan pada partisipan 2, beliau mengaku hanya mengalami kecemasan tentang perubahan kehidupannya. Partisipan 3 menyatakan bahwa tekanan psikologis yang beliau alami adalah pada saat sebelum bercerai dengan suami akibat tidak kondusifnya rumah tangga beliau dan kebutuhan keluarga yang tidak dipenuhi oleh suami.

"Kasaran e yo, maafya Yok, wes magang dadi rondo ngunu loh." (HC121018:196)

“...saya nggak menganggapnya stres sih, cuman ada semacam... "Gimana ya? Bisa nggak ya?" Tapi ya memang harus bisa dan harus dijalani." (IF060119:62)

"...Ya itu stres, Ai liat keluargane Ai gak kondusif, terus papa'e Sinyo yo jarang kasih uang belanja." (AH090919:76)

INSAN Jurnal Psikologi dan Kesehatan Mental

Tahun 2020, Vol. 5(1), 71-87

doi: 10.20473/jpkm.v5i12020.71-87 


\section{c. Respon treshadap stres}

Dari pernyataan ketiga partisipan, diketahui setiap partisipan memiliki respon yang beragam terhadap stres yang mereka hadapi. Menurut Sarafino (1990), respon individu terhadap stres yang dihadapinya antara lain berupa; anxiety; anger dan aggression; apathy dan depression; dan cognitive impairment.

Anxiety yang dirasakan partisipan 1 pasca bercerai dengan suaminya berupa kesulitan dalam hal finansial untuk mencukupi kebutuhan hidup dan biaya pendidikan kedua anaknya. Pada partisipan 2, kecemasan yang dialami pascacerai berupa keresahan terhadap stigma seorang janda dari masyarakat. Sedangkan respon kecemasan yang dialami partisipan 3 berupa kondisi sangkar kosong dimasa depan ketika anak keduanya kelak sudah mandiri dan berkeluarga.

"Ketakutannya terus terang dalam hal finansial." (HC121018:202)

"Menyandang status janda gitu ya... ahahahhaha..." (IF060119:82)

"Paling yang Ai khawatirin ya yang kesepian itu Yo. Kan sekarang Ai masih ngurus si Sinyo, lha nanti lek Sinyo wes mandiri, wes keluarga gitu kan..." (AH090919:112)

Kemudian respon kemarahan dan agresi yang ditunjukan partisipan 1 pasca bercerai dengan suaminya adalah berupa perilaku uring-uringan atau marah tanpa sebab yang jelas saat sedang mengalami stres. Sedangkan dari pengakuan partisipan 2 dan 3 diketahui bahwa beliau tidak pernah menunjukan respon kemarahan atau agresi baik berupa fisik maupun verbal pasca bercerai dengan suaminya. Partisipan 3 lebih memilih berdoa dan berpasrah kepada Tuhan daripada meluapkan kemarahannya kepada orang lain atau objek disekitarnya.

"Ehh... Aku nggak ngerasakan itu ya. Tapi sempat ehh...mungkin aku ndak rasa, tapi budenya arek-arek itu sempet comment, "Dulu loh dek kowe iku biyen sempat tampak..." gitu seh uring-uringan... Anu, yowes pokoknya...sebelum cerai Yok..." (HC121018:232)

"Endak, ndak pernah ngerasa frustasi dan mengungkapkan..." (IF060119:114)

"Ehm... rasane enggak ya Yo, nggak pernah kayak gitu, frustasi terus marah gitu..." (AH090919:128)

“...ya semuane tak serahno Tuhan ae..." (AH090919:130)

Selanjutnya pada indikator apathy dan depression, diketahui bahwa ketiga partisipan mengaku tidak pernah menunjukan respon penarikan diri dari lingkungan sosial mereka saat mengalami stres pascacerai.

"Endak... Justru, ehh...juga budenya anak-anak, juga ada sahabatku yang sudah meninggal, dia menasihatkan bahwa, "Kowe kudu tetep bersosialisasi Dan, jangan menarik diri!"..." (HC121018:254) "Saya...endak...endak...endak, endak pernah... Karena kekuatan saya disitu..." (IF060119:136)

"Ehm, enggak kok Yo. Justru setelah cerai itu, Ai malah lebih sering kumpul sama temen-temen'e Ai, temen gereja, ya termasuk sama maтати..." (AH090919:136)

Sedangkan pada indikator cognitive impairment, partisipan 1 kerap merasa sulit berkonsentrasi saat bekerja pasca bercerai dengan suaminya. Pada partisipan 2 diketahui konsentrasi beliau juga kerap teralihkan, namun hal tersebut bukan respon stres akibat perceraian yang dialaminya melainkan hanya kejenuhan dalam pekerjaannya sehari-hari. Sedangkan partisipan 3 merasa fokusnya kerap kali teralihkan ketika teringat akan biaya kuliah anak keduanya, namun hal tersebut tidak mempengaruhi kinerjanya.

“...Sulit konsentrasi... Ya tentunya terkait dengan biaya pendidikan...” (HC121018:262)

"Iya pernah. Kita punya masalah kecil-kecil aja kadang yo gak konsentrasi ehehe..." (IF060119:172)

"Tapi nek jadi apa...jadi kepikiran terus gitu ya endak." (IF060119:180) 
"Ya kadang gitu kalo kepikiran arek-arek, Sinyo terutama. Ya kebutuhan hidup e di Surabaya, SPP kampus e, gitu itu yang kadang jadi pikirane Ai, ya kadang pas ngapa-ngapain gitu ya rodok gimana ya..." (AH090919:148)

"Iya... kurang fokus." (AH090919:150)

"Nggak kok, rasane nggak pernah keganggu kerjaan e Ai..." (AH090919:152)

\section{Coping stress}

Pada penelitian ini, ketiga partisipan menerapkan setiap macam strategi coping yang dikemukakan oleh Lazarus dan Folkman (1984) untuk mengatasi stres yang mereka hadapi pasca bercerai dengan suami. Menurut Lazarus dan Folkman (1984), coping memiliki dua fungsi utama yaitu Problem-focused Coping dan Emotional-focused Coping. Macam strategi coping yang berfokus pada penyelesaian masalah antara lain; planful problem solving; confrontative; dan seeking social support for instrumental reason. Sedangkan macam strategi coping yang berfokus pada mengontrol respon emosi antara lain; distance; escape/avoidance; positive reappraisal; self-control; acceptance responsibility; dan seeking social support for emotional reason.

\section{a. Partisipan 1}

Partisipan 1 terlihat tidak banyak melakukan strategi problem-focused coping, yakni hanya dengan memutuskan untuk bekerja (planful problem solving), berkonsultasi dengan psikolog (seeking social support for instrumental reason), menghadapi suami dan wanita selingkuhan suaminya (confrontative), serta mengambil keputusan untuk bercerai dengan suaminya (planful problem solving). Selebihnya, partisipan 1 lebih berfokus pada pendekatan emosi dalam menghadapi stresnya pascacerai. Partisipan 1 juga kerap mencari dukungan sosial dari saudara dan kerabatnya dengan tujuan mendapat simpati dan menenangkan perasaan dan bukan berfokus untuk menyelesaikan masalahnya (seeking social support for emotional reason).

“...karena terus gonjang-ganjing itu kan aku juga mikir "loh aku kok gak nyambut gawe, engko nek ono opo-opo piye?", kan gitu ya..." (HC121018:32)

"Jadi aku fokus terusan... Aku fokus merawat ibuku... Ternyata benar Yok, dengan aku bercerai aku wes gak nggolek-nggoleki de'e maneh." (HC121018:244)

“...Dan aku nemoni wedokan iku. Aku menghadapi perempuan itu ..." (HC121018:52)

"Dan kayaknya dia juga gak ada itikad untuk, untuk baik, gitu lho Yok." (HC121018:64)

“...mendekati detik-detik ujian SD kan ada konseling di sekolahnya anak-anak itu..." (HC121018:56)

"Kan, ada...psikolog atau psikiaternya ya. Terus aku, kasarane ya mek curcol ngunu yo..." (HC121018:58)

"Ada banyak. Kebetulan aku banyak kawan dekat, jadi kita saling sharing. Onok konco sing podo-podo posisine koyok aku, jadi kita kayak suka saling cocok-cocokan..." (HC131018:94)

Pada strategi coping distance, partisipan 1 cenderung berperilaku seolah tidak sedang menghadapi masalah dan melihat sisi baik dari permasalahan yang terjadi. Partisipan 1 juga menerapkan strategi coping escape/avoidance berupa mengkhayal tentang bagaimana seharusnya situasi itu terjadi dan mencoba membuat diri sendiri nyaman dengan cara jalan-jalan dan berbelanja bersama anakanaknya. Strategi coping positive reappraisal yang diterapkan partisipan 1 berupa keyakinan bahwa dirinya akan baik-baik saja dan dengan adanya masalah perceraian yang dialaminya akan membuatnya lebih mengerti dan semakin dewasa.

\footnotetext{
“...kepada orang lain apakah tante pernah menunjukan kesedihan tante?" (A121018:371)

"Enggak." (HC121018:372)

“...Kalau aku sisi positifnya baik, karena aku berpikiran begini, ehh...karena bapaknya itu nanti, takutnya ngekek'i contoh sing gak apik ..." (HC131018:4)
} 
"Tapi kok yo nang aku kok yo damai ae yo? Ngunu lho..." (HC131018:16)

"Aku mikir begini Yok ... koyok'e nek aku tetep nang Khatolik..." (HC131018:62)

"Bisa jadi aku nggak cerai deh Yok..." (HC131018:64)

"Kemangkelanku itu, aku mung karo anak-anakku, mung nang Kebun Binatang, mung nang Mall...koyo ngunu...shopping..." (HC131018:262)

“...jadi takjadikan instropeksi aja ya..." (HC121018:386)

"Ternyata, "Oh, gak bener ya..." gitu aja..." (HC121018:388)

“...Jadi aku wes nyangoni arek-arek iki bahwa, "Jangan contoh bapak ibumu nak. Cari pendamping itu yang bener-bener sesuai"..." (HC121018:392)

Penerapan strategi coping self-control pada partisipan 1 berupa membiarkan masalah yang terjadi terbuka dengan sendirinya, mengikuti Kursus Evangelisasi untuk menjaga perasaannya agar tidak terpengaruh oleh hal-hal negatif lain serta berkaca pada orang terdekatnya tentang pengambilan keputusan dan penyelesaian masalah. Partisipan 1 juga menerapkan strategi coping acceptance responsibility berupa mengkritik diri sendiri, menyadari bahwa dirinya juga ikut andil memunculkan masalah, berjanji pada diri sendiri bahwa segala sesuatu akan berubah suatu saat nanti, serta memaafkan dan mengambil tindakan untuk mengubah situasi.

"Enggak menutupi... Dan aku juga ora ngumbar ..." (HC131018:104)

"Tapi begitu aku sudah kursus evanjelisasi itu, terus aku ngene tok, "Ohh...ternyata ada ya orang yang ngomongnya itu seperti ini"..." (HC131018:122)

"Gitu aja Yok, memaklumi..." (HC131018:124)

"Akhirnya aku berguru sama dia ... Karena dari situ aku ingin tahu pikirane wedok iku yoopo toh, wong wes eruh wes nduwe bojo..." (HC131018:148)

"Ohh..." Berarti satu, orang kalau sudah cinta, kasmaran, jatuh cinta...itu cinta buta itu wes bener Yok..."

(HC131018:154)

"Ya aku harus ngakoni lah Yok bahwa, ndak semuanya juga kok aku bener..." (HC131018:188)

"Paling nggak itu untuk instropeksiku. "Oh mungkin ini ya, aku harusnya nggak seperti ini ya, makanya kok suamiku seperti itu"..." (HC131018:184)

"Pasti akan takusahakan Yok, anak lanang-lanang iki... Ben hidupnya lebih baik dari bapak-ibuk'e..." (HC131018:200)

\section{b. Partisipan 2}

Pada partisipan 2, strategi coping planful problem solving yang diterapkan berupa memahami permasalahan yang telah terjadi dan berusaha keras menyelesaikannya, membuat perencanaan dan melaksanakannya, berusaha mengubah keadaan agar lebih baik, serta mencari jalan keluar dengan berkaca dari pengalaman masa lalu. Selanjutnya, strategi coping confrontative yang diterapkan partisipan 2 berupa mengungkapkan kemarahannya kepada suami dan keluarga suaminya, memutuskan untuk bercerai dengan suaminya, dan membiarkan perasaan sakit hatinya pergi.

"Sadar, saya tau resikonya, kondisi ataupun keadaan lingkungan itu kayak apa, menerima saya bagaimana... Saya tau pasti akan terjadi seperti itu..." (IF060119:214)

“...semacam evaluasi. "Kenapa ya saya sampai dikondisi seperti ini?"..." (IF060119:228)

“...Ya kalaupun saya ditanya, pengen menikah lagi? lya..." (IF060119:238)

“...Nah, kalaupun ketemu ya, bisa saja nanti pada suatu saat menikah." (IF060119:244)

“...saya pasti akan cari jalan keluar yang lain, dengan berkaca dengan kejadian yang lalu..." (IF060119:274)

“...saya marah ke suami saya. Dan pada waktu itu ke keluarganya yang ada disana gitu lho...” (IF060119:348)

"Karena menurut saya keluarganya itu tahu, tapi tidak memberi tahu..." (IF060119:350)

“...Jadi ya, ya sudah saya yang mengundurkan diri” (IF060119:302) 
"Saya menghilangkan sakit hati ketika ketemu temen-temen, keluarga atau siapapun yang punya nasib sama dengan saya terus sharing sama saya gitu..." (IF060119:352)

Strategi coping seeking for social support yang lebih difokuskan partisipan 2 adalah instrumental reason, yakni berupa mencari informasi pada orang lain tentang situasi yang dihadapi serta mempertimbangkan saran-saran yang telah diberikan. Sedangkan untuk emotional reason, penerapannya berupa menceritakan perasaannya pada keluarga dan kerabat terdekatnya serta menerima simpati dan pengertian dari mereka.

"Iya, iya... Iya, pasti saya ceritain..." (IF060119:388)

"Secara tidak langsung, pasti akan menyarankan sesuatu ya..." (IF060119:392)

"Ya... Masih mempertimbangkan..." (IF060119:396)

“...Mungkin pada suatu saat bisa saya lakukan atau saya jalankan gitu..." (IF060119:398)

"Iya... Nggak hanya permasalahannya, tapi perasaan juga... Iya..." (IF060119:406)

"Mereka dapat memahami apa yang saya rasakan, apa yang saya jalani, apa yang terjadi pada kehidupan saya..." (IF060119:414)

Bentuk penerapan strategi coping distance partisipan 2 adalah menganggap perceraian yang dialaminya tersebut tidak mempengaruhi masa depannya, mencoba untuk melupakan masalah, melihat sisi baik dari permasalahan yang terjadi, serta mencoba menerima takdir. Kemudian, strategi coping escape/avoidance yang diterapkan adalah berharap situasi akan berubah dan mencoba membuat diri sendiri nyaman dengan cara jalan-jalan dan nongkrong. Partisipan 2 juga menerapkan strategi coping positive reappraisal yang berupa keyakinan bahwa dirinya akan baikbaik saja.

"Iya, serius... Meskipun ya, menurut saya itu kan tidak mempengaruhi masa depan saya..." (IF060119:450)

"Lupakan aja hehehe... Kan kehidupan kita tidak berhenti di situ saat perceraian itu terjadi..." (IF060119:486)

"Bagi anak saya, dia jadi orang yang mungkin lebih mirip-mirip ke saya. Lebih bisa mandiri, lebih bisa menghadapi situasi dan kondisi keadaan tanpa kehadiran bapak." (IF070119:10)

"Iya, takdir. Kehidupan manusia itu kan ada yang ngatur ya..." (IF070119:24)

"Jadi harapannya ketika hal itu terjadi, harapan saya paling banyak ataupun paling takharapkan itu semua baik-baik saja. Dan saya berusaha untuk menjadi semuanya baik-baik saja hahaaha..." (IF070119:38)

"Hobi ehehehe..." (IF070119:46)

"Terus apa ya... Ehm kumpul keluarga..." (IF070119:48)

"Yakin. Saya kan pasti tau dengan potensi diri saya gitu Iho..." (IF070119:62)

"Saya tau bisa mengatasi semuanya sendiri lah... Dan alhamdullilah-nya lagi itu sampai sekarang memang saya bisa gitu Iho, jadi saya yakin saya bisa." (IF070119:64)

Strategi coping self-control yang diterapkan partisipan 2 antara lain; mencoba menyimpan perasaan dalam diri sendiri, mencegah orang lain tahu seberapa buruk masalah yang terjadi, membiarkan masalah yang terjadi terbuka dengan sendirinya, serta menjaga perasaan agar tidak terpengaruh oleh hal-hal lain yang dapat menambah stres. Kemudian, strategi coping acceptance responsibility yang diterapkan berupa mengkritik diri sendiri, menyadari bahwa dirinya ikut memunculkan masalah, berjanji pada diri sendiri bahwa segala sesuatu akan berubah suatu saat nanti, memaafkan pihak-pihak yang bersangkutan dalam memunculkan masalah tersebut, serta menerima tanggung jawab untuk mengubah situasi yang dialaminya.

"Kebanyakan saya simpan sendiri, terutama kalau sedih ataupun kalau ada permasalahan. Tapi kalau seneng, itu saya bisa menikmati dengan orang lain gitu..." (IF070119:66)

"Iya, Mencegah orang lain tahu..." (IF070119:74)

INSAN Jurnal Psikologi dan Kesehatan Mental

Tahun 2020, Vol. 5(1), 71-87

doi: 10.20473/jpkm.v5i12020.71-87 
"Masalah dia berpendapat ngene ngene ngene, ataupun mungkin kasarane jadi rasan-rasan orang, wis biarin aja..." (IF070119:88)

"Iya, cuek ae mas. Pada dasarnya saya ini orangnya wes cuek gitu lho..." (IF070119:98)

"Kenapa saya bisa jadi cuek, itu kan karena saya tahu, ketika sing diomongo "Iyo, ancene salahku, wes..." tahu saya. Saya menyalahkan diri saya sendiri? Ya pernah." (IF070119:126)

"Andil kesalahan saya disitu. Dulu ketika LDR, saya sudah ditawari untuk pindah, nah tapi karena saya disini masih ada orang tua dan tinggal satu, saya masih memberati orang tua gitu lho. Akhirnya yasudah... Itu yang membuat saya jadi merasa bahwa saya juga salah gitu lho..." (IF060119:344)

"Percaya, pasti akan berubah..." (IF070119:138)

"Memaafkan. Karena percuma mas, memendam rasa seperti itu kan nanti akhirnya sakit 'disini' sendiri..." (IF070119:142)

"Iya, saya yang bertanggung jawab. Semua kejadian ini ataupun, kesininya itu tanggung jawab saya. Apapun yang terjadi dalam hidup saya dan anak saya sekarang ataupun yang pascacerai ini menjadi tanggung jawab saya." (IF070119:156)

\section{c. Partisipan 3}

Pada partisipan 3, strategi coping planful problem solving yang diterapkan berupa memahami permasalahan yang telah terjadi dan berusaha keras menyelesaikannya, membuat perencanaan dan melaksanakannya, serta berusaha mengubah keadaan agar lebih baik. Selanjutnya, bentuk confrontative yang dilakukan partisipan 3 adalah mengungkapkan kemarahannya kepada suaminya, memutuskan untuk bercerai dengan suaminya, dan membiarkan perasaan sakit hatinya pergi.

"Iya kok Yo, Ai wes tau apa-apane nanti yang bakal Ai hadapi pas bercerai sama si Om." (AH090919:154)

“...Ai kudu siap mental menjadi seorang single parent...” (AH090919:158)

"Untuk finansial Ai kerja jualan tahu, sama ada bantuan dari Cece, sama kadang ya dari sodara-sodara'e Ai. Terus kalo psikologisnya anak-anak sih tak rasa mereka udah gede dan mereka kan ya wes jembek gitu rasane sama papa'e..." (AH090919:176)

“...yang paling penting saat itu, ya sekarang juga, itu Sinyo bisa terus kuliah sampek lulus, bisa dapet kerja dan hidup'e bisa lebih baik dari Ai gitu Yo..." (AH090919:188)

"Iya. Pasti marah Ai awal-awal itu..." (AH090919:206)

"Marah ke si Om pastinya ..." (AH090919:208)

"Pastine ke gereja ya Yo. Ngilangno sakit hati itu yang paling pertama ya ibadah sih kalo menurut Ai..."

(AH090919:216)

Strategi coping seeking for social support yang lebih difokuskan partisipan 3 adalah emotional reason, yakni berupa menceritakan perasaan yang dialaminya pada keluarga dan sahabat-sahabatnya. Sedangkan untuk instrumental reason, partisipan 3 mencari informasi pada orang lain tentang situasi yang dihadapi, serta menceritakan masalahnya dan meminta saran pada orang yang berpengalaman.

“...Kita kalo kumpul-kumpul gitu, nongkrong, yawes mesti curhat-curhat gitu, ya namanya ibu-ibu toh yo ahahaha..." (AH090919:222)

“...Pasti Ai selalu mempertimbangkan saran-saran dari orang yang kasarane 'udah berpengalaman' gitu Yo..." (AH090919:226)

Strategi coping distance yang diterapkan partisipan 3 adalah dengan tidak menganggap terlalu serius masalahnya, berperilaku seolah tidak menghadapi masalah, mencoba untuk melupakan masalah, melihat sisi baik dari permasalahan yang terjadi, serta mencoba menerima takdir.

"Kalo lagi ada masalah gitu, paling ya biasa aja Yo..." (AH090919:240) 
"Masalah besar ataupun kecil, Ai lebih sering kayak diem gitu. Ai lebih sering doa, minta pertolongan Tuhan ..." (AH090919:242)

"Ya lupakan aja Yo hehehe..." (AH090919:250)

“...ya paling nggak dari peristiwa ini, anak-anak bisa ngambil pelajaran dari itu..." (AH090919:268)

"Takdir Yo. Yang Ai percaya sih semuanya bisa terjadi karena seijin Tuhan. Ya walaupun kita semua kan dikasih pilihan ya dalam hidup..." (AH090919:278)

Strategi coping escape/avoidance yang diterapkan partisipan 3 adalah berharap situasi akan berubah serta mencoba membuat diri sendiri nyaman dengan cara jalan-jalan dengan anaknya dan nongkrong dengan sahabat-sahabatnya. Partisipan 3 juga menerapkan strategi coping positive reappraisal yang berupa keyakinan bahwa dirinya akan baik-baik saja, serta menjadikan perceraian yang dialaminya sebagai pelajaran bagi kedua anaknya kelak.

"Harapan Ai sih untuk saat ini cuma kedua anak Ai bisa mapan lah gitu intinya..." (AH090919:282)

"Lek hidup'e Ai ya pokoknya bisa nyukupi kebutuhan sehari-hari, bisa liat anak-anak bahagia aja wes seneng Ai..." (AH090919:284)

“...paling doa..." (AH090919:288)

“...Terus nongkrong sama jalan-jalan paling Yo...” (AH090919:290)

“...Walaupun kenyataannya memang Ai mengalami kegagalan, tapi harapan Ai cuma buat anak-anak ini bisa ngambil pelajaran dari Ai, jangan sampai mengalami hal yang sama kayak Ai..."

(AH090919:298)

Penerapan self-control pada partisipan 3 antara lain; mencegah orang lain tahu seberapa buruk masalah yang terjadi, membiarkan masalah yang terjadi terbuka dengan sendirinya, menjaga perasaan agar tidak terpengaruh oleh hal-hal lain yang dapat menambah stres, serta berkaca dari sosok panutanya dalam menyelesaikan masalahnya. Kemudian, strategi coping acceptance responsibility yang diterapkan partisipan 3 berupa mengkritik diri sendiri, menyadari bahwa dirinya ikut memunculkan masalah, berjanji pada diri sendiri bahwa segala sesuatu akan berubah suatu saat nanti, memaafkan pihak-pihak yang bersangkutan dalam memunculkan masalah tersebut, serta menerima tanggung jawab untuk mengubah situasi yang dialaminya.

"Pernah ya rasae, untuk membatasi. Terutama orang-orang yang gak seberapa deket gitu, kan gak perlu lah mereka tau seberapa parah kondisi yang Ai alami ini..." (AH090919:304)

"Ya wes biarno, gak usah sok-sok'an ditutupi. Buat apa juga mengelak kalo memang benar keadaan Ai seperti yang mereka bilang ya sudah biarno ae..." (AH090919:308)

"Cuek aja Yo. Orang gossip ya dicuekin aja, paling lak berhenti sendiri..." (AH090919:312)

"Ada beberapa orang sih Yo, dan salah satunya lagi-lagi mamamu..." (AH090919:320)

"Nah itu banyak yang Ai pelajari dari mamamu. "Kok bisa ya seorang ibu nggede'no anak dua dari kecil sampek gede, seorang diri?"..." (AH090919:326)

"Ya Ai sih sempat mikir, "Apa aku ini pernah melakukan kesalahan, atau berbuat dosa gitu di masa lalu, makane terjadi kayak gini..."' (AH090919:338)

“...Secara tidak langsung Ai ada andil perceraian itu bisa terjadi, walapun semua orang tetep nyalahno papa'e Sinyo, dan memang faktanya seperti itu." (AH090919:344)

"Iya, pasti Ai tetep usahakan yang terbaik buat anak-anak ini, terutama Sinyo, kalo Cece kan udah mapan lah..." (AH090919:346)

"Pada akhirnya sih iya, Ai memaafkan. Walaupun cukup sulitya..." (AH090919:350)

"Iya. Karena gimana-gimana, tetep Ai yang bertanggungjawab untuk masa depan anak-anak ini, ya termasuk hidup'e Ai ini..." (AH090919:358) 


\section{I S K US I}

Stres ibu tunggal yang dipahami dalam penelitian ini adalah stres yang muncul pasca ibu tunggal sah bercerai dengan suaminya. Penelitian ini berfokus untuk menunjukan gambaran stres yang muncul pascacerai ibu tunggal yang bekerja.

Dalam penelitian ini ditemukan bahwa ibu tunggal mengalami gejala stres psikologis dan perilaku, namun pada partisipan 2 tidak mengalami gejala fisik. Hal tersebut membuktikan bahwa gejala stres tidak selalu memunculkan gejala fisik pada individu. Stres karena perceraian memberikan berbagai macam dampak pada ibu tunggal. Ibu tunggal merasakan dampak perceraian berupa perubahan identitas, yakni berstatus janda. Respon terhadap stres pascacerai yang muncul pada ibu tunggal adalah kecemasan, kemarahan dan agresi, serta penurunan fungsi kognitif, namun tidak memunculkan respon berupa ketidakberdayaan dan depresi. Temuan ini tidak sesuai dengan teori yang dikemukakan Sarafino (1990) dimana individu akan memunculkan reaksi psikologis berupa menarik diri dan merasa tidak berdaya menghadapi peristiwa-peristiwa yang tidak terkontrol.

Pada penelitian ini juga ditemukan perbedaan penghayatan emosi terhadap stresor perceraian antar ibu tunggal. Partisipan 1 dan 3 memiliki penghayatan emosi yang cenderung negatif terhadap perceraiannya dan menganggap stresor tersebut sebagai peristiwa yang traumatis. Sedangkan partisipan 2 memiliki penghayatan emosi yang positif terhadap perceraiannya dan hanya menganggap stresor minor sehingga bisa cepat bangkit dari keterpurukan. Temuan tersebut memiliki keterkaitan dengan resiliensi, yakni kemampuan manusia untuk menghadapi, mengatasi, dan menjadi kuat atas kesulitan yang dialaminya (Grotberg, 1999). Hal ini sesuai dengan hasil penelitian Aprilia (2013) dimana apabila resiliensi dalam diri seseorang itu meningkat, maka akan mampu mengatasi masalahmasalah apapun, mampu untuk meningkatkan potensi-potensi diri, menjadi optimis, muncul keberanian dan kematangan emosi.

Dalam penelitian ini juga ditemukan kompleksitas stresor pascacerai ibu tunggal. Ibu tunggal tidak hanya terfokus pada perceraian. Kebimbangan akan kepercayaan, bullying dari saudara, serta tekanan dari anak yang menyalahkannya terkait perceraian yang dialaminya merupakan bentuk stress ganda bagi ibu tunggal. Hal tersebut mengakibatkan naiknya tekanan darah, sulit berkonsentrasi, dan marah tanpa sebab. Kompleksitas stresor pada ibu tunggal dapat mempengaruhi penghayatan stresor perceraian. Ibu tunggal yang memiliki stresor yang kompleks dan menghayatinya secara negatif lebih banyak melaporkan pengalaman yang buruk serta cenderung bergantung pada coping emosional. Sedangkan ibu tunggal yang memiliki sedikit stresor serta menghayatinya secara positif menganggap perceraiannya sebagai tantangan dan cenderung melakukan coping yang berfokus penyelesaian masalah. Temuan tersebut sejalan dengan hasil penelitian Khumas dkk (2015) dimana keyakinan untuk hidup lebih baik setelah bercerai, khususnya memperoleh pasangan baru merupakan salah satu faktor yang memengaruhi kemantapan perempuan untuk bercerai.

Setiap ibu tunggal dalam penelitian ini melakukan semua jenis coping yang dikemukakan oleh Lazarus dan Folkman (1984) untuk mengatasi stres pasca bercerai dengan suaminya. Folkman, dkk (1986) mendeskripsikan tiga macam strategi coping dalam problem-focused coping, yaitu; planful problem solving, confrontative, dan seeking social support for instrumental reason. Masalah yang dialami ibu tunggal adalah sakit hati dan tekanan mental karena mengetahui suami mereka berselingkuh dengan wanita lain. Hal ini selaras dengan Rathus dan Nevid (2002) yang menyatakan bahwa suatu kondisi yang menekan fisik dan psikis akibat adanya tuntutan dalam diri dan lingkungan dapat menimbulkan stres dan akan menstimulasi individu untuk bereaksi. Selain itu, diketahui bahwa setiap partisipan ibu tunggal meminta saran dari orang lain. Hal ini dapat dipahami bahwa lingkungan dimana individu berada khususnya lingkungan terdekat seperti keluarga, sangat menentukan dalam memberikan dukungan untuk menghadapi tekanan yang dialami individu (Schabracq, dkk, 2003).

INSAN Jurnal Psikologi dan Kesehatan Mental

Tahun 2020, Vol. 5(1), 71-87

doi: 10.20473/jpkm.v5i12020.71-87 
Selain problem-focused coping, ibu tunggal dalam penelitian ini juga menerapkan pendekatan emotionalfocused coping yang dideskripsikan Folkman, dkk. (1986) dalam enam strategi coping, yakni; distance, escape/avoidance, positive reappraisal, self-control, acceptance responsibility, dan seeking social support for emotional reason. Dari hasil penelitian ditemukan bahwa ibu tunggal tidak bisa menerima bahwa perceraian yang dialaminya merupakan sebuah takdir. Hal tersebut berkaitan dengan latar belakang partisipan ibu tunggal yang mengalami kebingungan kepercayaan. Temuan ini sejalan dengan penelitian Cintiawati dan Na'imah (2015) tentang krisis identitas, yakni karena krisis identitas timbul dari konflik internal yang berawal dari masa transisi itu, maka perlu segera mendapat penyelesaian yang baik dengan mengelola ulang atau membentuk ulang identitas dirinya.

Dari data yang didapat melalui wawancara, terdapat perbedaan strategi coping yang menonjol dari setiap partisipan ibu tunggal. Partisipan 1 dan 3 cenderung lebih dominan melakukan coping yang berfokus pada pendekatan emosional (emotional-focused coping). Hal tersebut dikarenakan strategi coping ini lebih berorientasi pada emosi yang merupakan usaha untuk meredakan atau mengelola stres emosional yang muncul ketika individu berinteraksi dengan lingkungan (Bakhtiar \& Asriani, 2015). Sedangkan pada partisipan 2 cenderung melakukan coping yang berfokus pada penyelesaian masalah (problem-focused coping).

\section{S I M P U L A N}

Berdasarkan hasil penelitian, terdapat tiga dimensi gambaran stres pascacerai pada ibu tunggal yang bekerja yakni gejala stres, sumber stres, dan respon trerhadap stres. Dari gambaran stres yang berbedabeda, terdapat satu kesamaan sumber stresor penyebab perceraian pada ketiga partisipan yaitu adanya orang ketiga dalam rumah tangga mereka.

Untuk mengatasi stres pascacerai, ketiga partisipan menerapkan setiap macam strategi coping yang dikemukakan Folkman (1986), yakni planful problem solving, confrontative, seeking social support, distance, escape/avoidance, positive reappraisal, self-control, dan acceptance responsibility. Hasil penelitian menunjukan ketiga partisipan mencoba setiap strategi coping yang ada dan mempertahankan coping yang paling membuat mereka nyaman. Partisipan 1 cenderung mencari dukungan sosial berupa informasi atau nasehat dan simpati dari lingkungan keluarga dan gereja. Kemudian, partisipan 2 cenderung mengutamakan kontrol diri yang baik untuk strategi coping stress-nya. Sedangkan partisipan 3 cenderung berfokus pada menerima tanggungjawab sebagai pondasi mental yang kuat dalam menghadapi masalahnya sehari-hari.

\section{U C A P A N T ERIMA KASIH}

Penulis menyampaikan terimakasih kepada Fakultas Psikologi Universitas Airlangga selaku instansi pendidikan dan penyedia fasilitas penunjang penelitian, serta terimakasih kepada setiap partisipan selaku pemberi data penelitian dan significant other selaku informan.

\section{DEKLARASI POTENSI TERJADINYA KONFLIK KEPENTINGAN}

Ario Chandra Jonathan dan Ike Herdiana tidak bekerja, menjadi konsultan, memiliki saham, atau menerima dana dari perusahaan atau organisasi manapun yang akan mengambil untung dari diterbitkannya naskah ini dan telah mengungkapkan bahwa ia tidak memiliki afiliasi selain yang telah disebutkan di atas. 


\section{PUSTAKA ACUAN}

Aprilia, W. (2013). Resiliensi dan Dukungan Sosial pada Orang Tua Tunggal (Studi Kasus pada Ibu Tunggal di Samarinda. eJournal Psikologi, I(3), 268-279.

Asilah, \& Hastuti, D. (2014). Hubungan tingkat stress ibu dan pengasuhan penerimaan-penolakan dengan konsep diri remaja pada keluarga bercerai. Jurnal Ilmu Keluarga dan Konsumen, VII(1), 10-18.

Atkinson, R. (1987). Pengantar Psikologi. Jakarta: Erlangga.

Bakhtiar, M. I., \& Asriani. (2015). Efektivitas Strategi Problem Fokused Coping dan Emotion Focused Coping dalam Meningkatkan Pengelolaan Stres Siswa di SMA Negeri 1 Barru. Jurnal Ilmu Pendidikan, Psikologi, Bimbingan dan Konseling, V(2), 69-82.

Belsky, J. (1997). The Adult Experience. USA: West Publishing Company.

Boyatzis, R. (1998). Transforming Qualitative Information: Thematic Analysis and Code Development. California: SAGE Publication.

Cintiawati, N., \& Na'imah, T. (2015). Identitas Diri pada Remaja dari Keluarga Berbeda Agama (Studi Fenomenologi pada Remaja dari Keluarga dengan Latar Belakang Agama yang Berbeda. SAINTEKS, XII(2), 86-93.

Fatimah, S., \& Nurdin. (2015). Strategi pemenuhan kebutuhan hidup single parent. Jurnal Equilibrium, III(1), 38-46.

Folkman, S., Lazarus, R., Dunkel-Schetter, C., DeLongis, A., \& Gruen, R. (1986). Dynamics of a stressful enconter: Cognitive appraisal, coping, and enconter outcomes. Journal of Personality and Social Psychology, V(50), 992-1003.

Grotberg, E. (1999). Tapping Your Inner Strength. Oakland, CA: New Harbinger Publication, Inc.

Khumas, A., Prawitasari, J. E., Retnowati, S., \& Hidayat, R. (2015). Model Penjelasan Intensi Cerai Perempuan Muslim di Sulawesi Selatan. Jurnal Psikologi, XLII(3), 189-206.

Kotwal, N., \& Prabhakar, B. (2009). Problems faced by single mothers. Journal Social Science, XXI(3), 197204.

Lazarus, \& Folkman. (1984). Stres, Apraisal, and Coping. New York: Springer Publishing Company, Inc.

Moleong, L. (1998). Metode Penelitian Kualitatif. Bandung: Remaja Rosdakarya.

Nair, H., \& Murray, A. (2005). Predictor of attachment security in preschool children from intact and divorced families. The Journal of Genetic Psychology, CLXVI(3), 245-263.

Naufaliasari, A., \& Andriani, F. (2013). Resiliensi pada wanita dewasa awal pasca kematian pasangan. Jurnal Psikologi Industri dan Organisasi, II(2), 264-269.

Negeri, B. (2013). Subjective well being pada ibu yang memiliki anak tuna rungu. Jurnal Ilmiah Mahasiswa Universitas Surabaya, II(2), 2-16.

Papalia, D., Olds, S., \& Feldman, R. (2009). Human Development edisi 10 Perkembangan Manusia Buku 2. Jakarta: Salemba Humanika.

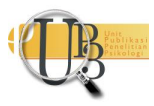


Pitasari, A., \& Cahyono, R. (2014). Coping pada ibu yang berperan sebagai orang tua tunggal pasca kematian suami. Jurnal Psikologi Pendidikan dan Perkembangan, III(1), 37-41.

Poerwandari, E. (2007). Pendekatan Kualitatif untuk Penelitian Perilaku Manusia. Jakarta: LPSP3 Fakultas Psikologi Universitas Indonesia.

Qaimi, A. (2003). Single Parent: Peran Ganda Ibu dalam Mendidik Anak. (M. Bafaqih, Trans.) Bogor: Penerbit Cahaya.

Rathus, \& Nevid. (2002). Clinical Psychology. New York: John Willey \& Sons.

Robbins, S., \& Coulter, M. (2007). Manajemen (8th ed.). (H. Slamet, Trans.) Jakarta: PT Indeks.

Robbins, S., \& Judge, T. (2007). Perilaku Organisasi (12th ed.). (D. Angelica, R. Cahyani, \& A. Rosyid, Trans.) Jakarta: Salemba Empat.

Sarafino, E. (1990). Health Psychology. Singapore: John Willey \& Sons. Inc.

Sari, P. (2013). Family Coping with Stress ibu tunggal dan anak paska perceraian di Surabaya. Jurnal Online Departemen Komunikasi FISIP Unair, II(2), 123-137.

Sasongko, A. (2014, November 14). Republika. Retrieved April 14, 2017, from http://www.republika.co.id/berita/nasional/umum/14/11/14/nf0ij7-tingkat-perceraianindonesia-meningkat-setiap-tahun-ini-datanya 